\title{
The Possible Emergence of Life and Differentiation of a Shallow Biosphere on Irradiated Icy Worlds: The Example of Europa
}

\author{
Michael J. Russell, Alison E. Murray, ${ }^{1}$ and Kevin P. Hand ${ }^{1}$
}

\begin{abstract}
Irradiated ice-covered ocean worlds with rocky mafic mantles may provide the conditions needed to drive the emergence and maintenance of life. Alkaline hydrothermal springs-relieving the geophysical, thermal, and chemical disequilibria between oceans and tidally stressed crusts-could generate inorganic barriers to the otherwise uncontrolled and kinetically disfavored oxidation of hydrothermal hydrogen and methane. Ionic gradients imposed across these inorganic barriers, comprising iron oxyhydroxides and sulfides, could drive the hydrogenation of carbon dioxide and the oxidation of methane through thermodynamically favorable metabolic pathways leading to early life-forms. In such chemostatic environments, fuels may eventually outweigh oxidants. Ice-covered oceans are primarily heated from below, creating convection that could transport putative microbial cells and cellular cooperatives upward to congregate beneath an ice shell, potentially giving rise to a highly focused shallow biosphere. It is here where electron acceptors, ultimately derived from the irradiated surface, could be delivered to such life-forms through exchange with the icy surface. Such zones would act as "electron disposal units" for the biosphere, and occupants might be transferred toward the surface by buoyant diapirs and even entrained into plumes. Key Words: Biofilms-Europa—Extraterrestrial life-Hydrothermal systems. Astrobiology 17, 1265-1273.
\end{abstract}

\section{Introduction}

$\mathbf{O}$ N EARTH, the geochemical utility of life can, in part, be simplified to the hydrogenation of carbon dioxide. Such hydrogenations yield an ever-renewed stock of highly specified organic molecules - the so-called CHNOPS with a typical bonding motif -C-C $\left(\mathrm{H}_{2}\right)-\mathrm{N}(\mathrm{H})-\mathrm{C}-\mathrm{O}$ (Bernal, 1960; Lassiter, 1986; Fuchs, 1989, 2011). However, the significance of the proton and electron flux must also be appreciated, since those processes are at the root of life's role in free energy transfer and transformation (Mitchell, 1961; Szent-Györgyi, 1968). Viewed in these terms, life is a mechanism that hastens the flow of "hot" electrons to available electron acceptors (e.g., Steele, 2003; Russell et al., 2003, 2014; Nitschke and Russell, 2011). Here, we suggest that life may have emerged on irradiated icy worlds such as Europa, in part as a result of the chemistry available within the ice shell, and that it may be sustained still, immediately beneath that shell.

\section{The Drive to Life on Ice-Covered Ocean Worlds with Rocky Mantles}

In cases where ice-covered ocean worlds with rocky cores are subject to surface irradiation and tidal forces, such systems may reach a metastable dynamic state. In these systems, electron-bearing fuels will be produced in serpentinization (rock-water) reactions as salty ocean waters are reduced to hydrogen and formate on gravitation into the primitive ultramafic crust (Windman et al., 2007; Russell et al., 2010; Vance et al., 2016). Primeval (abiotic) methane could be leached concomitantly from the same source (e.g., Watanabe et al., 1983; Sherwood Lollar et al., 2007; McCollom and Donaldson, 2016). Likewise, hydrogen and methane could be entrained convectively to the ocean through widespread and continuous submarine alkaline hydrothermal activity (Hand et al., 2007; Vance et al., 2007, 2016; Vance and Goodman, 2009; Travis et al., 2012; Russell et al., 2014) (Fig. 1). Along

\footnotetext{
${ }^{1}$ Jet Propulsion Laboratory, California Institute of Technology, Pasadena, California.

${ }^{2}$ Division of Earth and Ecosystem Sciences, Desert Research Institute, Reno, Nevada.

(C) Michael J. Russell et al., 2017; Published by Mary Ann Liebert, Inc. This Open Access article is distributed under the terms of the Creative Commons License (http://creativecommons.org/licenses/by/4.0), which permits unrestricted use, distribution, and reproduction in any medium, provided the original work is properly credited.
} 


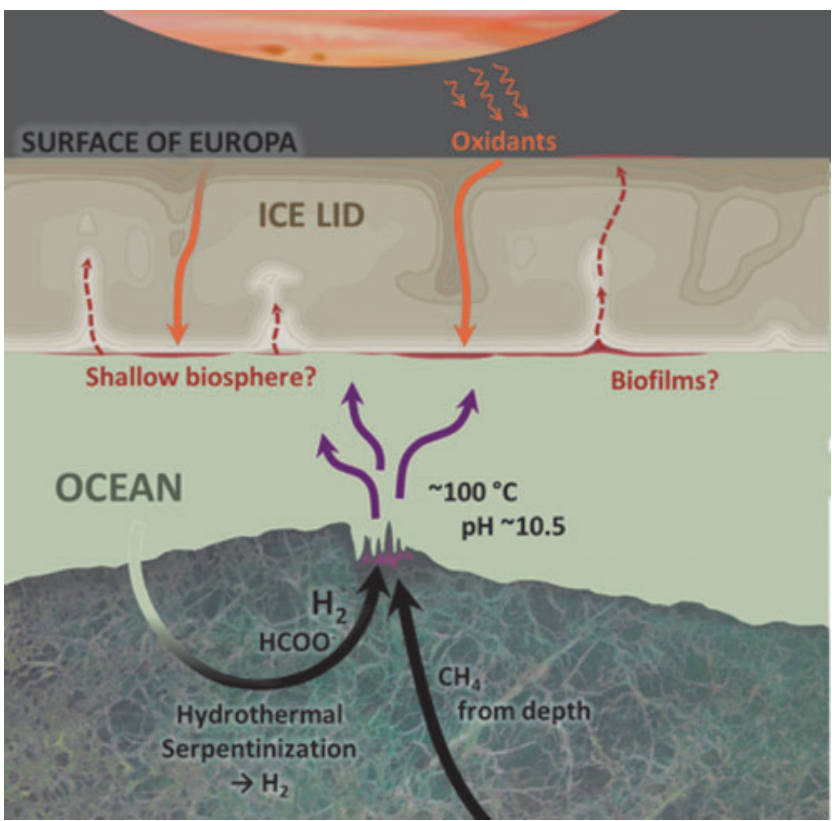

FIG. 1. Model for the emergence of life on Europa at an alkaline hydrothermal mound (Russell et al., 2014, and see Vance et al., 2016). Also indicated is a hypothesized rapid migration of microbes and nanobes entrained within buoyant thermal plumes toward oxidant-rich areas at the base of the ice lid. These areas act as "electron disposal units" and are derived through subduction of oxidants from the exterior produced by high-energy electron radiation from Jupiter (Bolton et al., 2002). In turn, portions of this shallow and buoyant biosphere may be returned to the surface through ice tectonics or sucked into the source regions of water vapor/ice jets on, for example, Europa and Enceladus (Squyres and Croft, 1986; Roth et al., 2014; Lorenz, 2016; Sparks et al., 2016; and McKay et al., 2008). Along with the standard methods for flying through any existing plumes and analyzing the surface, future missions could employ "Under-Ice Buoyant Rovers for Exploration" of the putative biosphere (Berisford et al., 2012, and see Ananthaswamy, 2013). The ice shell is partly based on Showman and Han (2005) and Kalousová et al. (2014). Not to scale.

with methane, the hydrothermal fluids feeding the springs could also have entrained vital nutrients in the form of further reduced volatiles to be expected on a moon such as Europa with a mantle and crust dominated by fayalite (ferrous ironrich olivine), that is, carbon monoxide, ammonia, and hydrogen sulfide (Fig. 1) (Anderson et al., 1998; Sohl et al., 2002; McDermott et al., 2015; and see Wood et al., 2006; Gaillard et al., 2015). Other entities could be leached into the same hydrothermal fluids, such as the all-important phosphorous (perhaps from dissolution of phosphide) along with the trace metals, including molybdenum, required of all Earthly life (Pasek et al., 2011; Schoepp-Cothenet et al., 2012; Russell et al., 2014; Pasek, 2016).

On Earth, hydrogen, or more precisely its component electrons and protons, is life's must-have fuel. And, given a supply of carbon dioxide and other, higher potential oxidants such as nitrate, nitrite, sulfite, sulfur, and ferric iron in early mildly acidic oceans, life may have been forced into being in order to resolve these electrogeochemical disequilibria. The best candidate for such interactions would be hydrothermal mounds and sediments comprising ferrous-ferric oxyhydroxides and sulfides precipitated where alkaline hydrothermal fluids interfaced acidulous ocean water (Russell et al., 1994, 2003, 2014; Pasek and Greenberg, 2012; Tosca et al., 2016; Halevy and Bachan, 2017). Such mounds could have functioned as long-lasting, stably operating electrogeochemical reactors (Russell, 2007). The vectorial proton and redox gradients obtaining at, and near, the surface of the mounds are comparable to those that "energize" life as we know it on Earth (Kelley et al., 2001; Martin et al., 2008; Branscomb and Russell, 2013; Herschy et al., 2014; Branscomb et al., 2017). Moreover, the transition metals required for catalysis-and which are affine with the active centers of metalloenzymeswould also be available in the oxyhydroxides and sulfides constituting the mounds (Nitschke et al., 2013).

It is these physicochemical disequilibria that are, in the alkaline hydrothermal vent model, proposed to be the founding drivers of biogenesis needed to reduce $\mathrm{CO}_{2}$ to simple organic acids, alcohols, and hydrocarbons, to fix nitrogen and to drive other required first-step endergonic reactions that eventuated in cellular life (Russell et al., 2003; Martin and Russell, 2007). We see such worlds as batteries with outputs approaching a volt or so (Russell and Hall, 1997), that drive prokaryotic cells with the same spatiality as natural fuel cells (Mitchell, 1967; Russell, 2007). And the specific iron-bearing minerals dosed with nickel and molybdenum-mainly green rust and lesser mackinawite and greigite - that make up such inorganic layers and micro-conduits constituting the metal-bearing electrodes of the precipitate mound have, it is proposed, the capability to couple the proton and redox gradients to carbon and nitrogen fixation (Génin et al., 2005, 2006, 2008; Nitschke et al., 2013; Barge et al., 2014, 2015a, 2015b; Russell et al., 2014; White et al., 2015; Branscomb et al., 2017; Halevy et al., 2017; cf. Mloszewska et al., 2012; Peacock et al., 2016).

\section{The Ensuing Biosphere}

In comparing active icy worlds such as Europa and Enceladus to our own planet, major differences must be taken into account (Pappalardo et al., 1998; Sotin et al., 2002; Waite et al., 2006, 2017; Nimmo et al., 2007; McKay et al., 2008; Schmidt et al., 2011; Glein et al., 2015). On Earth, the ocean is mostly solar heated. And ice-water associated interfaces are known to support dense congregations of life as a result of (i) Sun-derived energy infiltrating nutrient-bathed sea ice habitats (Fig. 2A, 2B), (ii) dissolved, reduced sulfur sources that drive chemoautotrophic biofilms in Arctic terrestrial cold-seep formations (Fig. 2C), or (iii) putative detrital organic matter supplies fueling under-ice-shelf ecosystems that even harbor multicellular life (Fig. 2D). On icy worlds, however, the oceans are heated from below, and the ice shells will confer upon the sub-ice ocean the "steady state" characteristics of a giant natural chemostat (Goodman et al., 2004; Glein et al., 2015). Under such conditions, organisms and biological processes could be limited by the availability of oxidants, that is, the compounds needed to "breathe" (Nealson et al., 2002). Iron and manganese oxides and oxyhydroxides, sulfuric acid, sulfates, sulfur, carbonates, and even oxygen itself are possible candidate electron acceptors produced and concentrated on the heavily irradiated surface of certain ice shells (Chyba and Hand, 2001; McCord et al., 2001; Carlson et al., 2002; Zolotov 

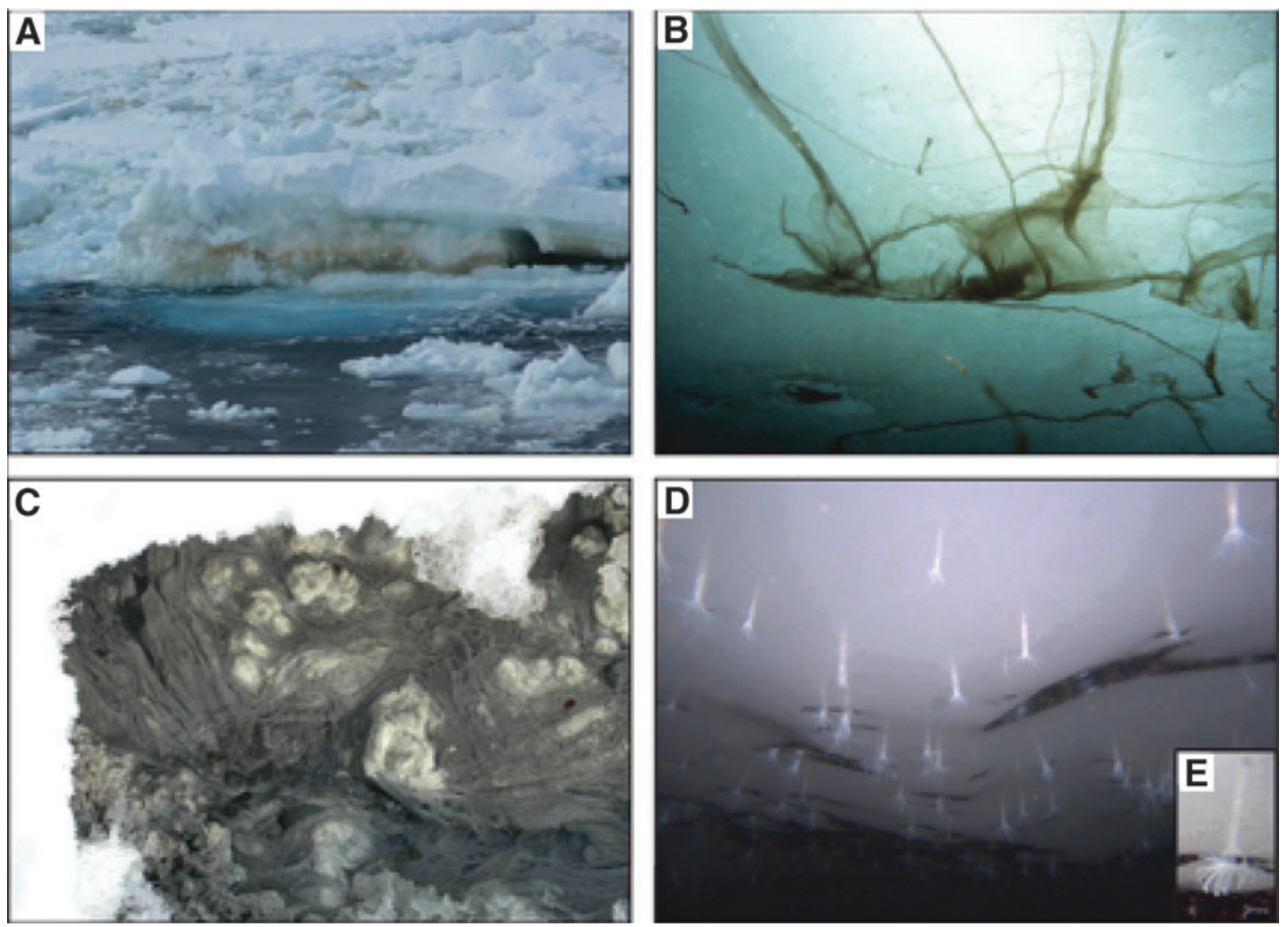

FIG. 2. Ice-water interfaces support dense communities of microscopic and even macroscopic life on Earth. (A) Dense multispecies communities of algae, bacteria, heterotrophic protists, and even multicellular invertebrates form annually under spring sea-ice conditions in the Southern Ocean when ample sunlight fuels photosynthesis of ice algae. The orange-brown carotenoid pigments in dense diatom aggregations in sea ice are visible to the eye in the image taken from the Northern Antarctic Peninsula in August (photo source: A.E. Murray). (B) Spring conditions in the Arctic also support large, macroscopic filamentous forms of the ice-associated diatom, Melosira arctica, shown attached to the underside of the sea ice. (@) AWI/Gutt, doi:10.1594/PANGAEA.820720). (C) Runoff from Gypsum Springs, a sulfurous spring on Axel Heiberg Island, in the Canadian High Arctic, is home to filamentous sulfur-oxidizing bacterial streamers that underlie the snow and ice cover, site GH-4 (water temperature $\sim 5-6.9^{\circ} \mathrm{C}$; image is $\sim 30 \mathrm{~cm}$ in diameter; Niederberger et al., 2009). (D) The underside of the Ross Ice Shelf has recently been found to harbor fields of the newly described ice-dwelling sea anemone Edwardsiella andrillae, which lives embedded in the ice. (E) Inset shows a close-up image of the under ice-embedded anemone, Edwardsiella andrillae. Diameter across tentacles is $\sim 1-2 \mathrm{~cm}$. The image was captured using the ROV SCINI at Coulman High site (adopted from Murray et al., 2016). The under-ice-shelf ecosystems on Earth though potentially sustained by fuels sourced from the open ocean may be relevant proxies for ice shells of outer Solar System ocean worlds. (Vick-Majors et al., 2016).

and Shock, 2003, 2004; Hand et al., 2007; Vance et al., 2014, 2016; and see Nealson et al., 2002; Lin et al., 2006; Milucka et al., 2012; Egger et al., 2017).

Hydrogen peroxide produced in the purest ice regions via radiolysis could subsequently react with hydrogen sulfide and ammonia in the ice, yielding oxidants (e.g., sulfite, nitrate, and nitrite) that are potentially more amenable as acceptors along metabolic pathways than just $\mathrm{CO}_{2}$ or carbonate (Hand and Brown, 2013; Loeffler and Hudson, 2015; cf. Zolotov and Shock, 2004; Wong et al., 2017). Early in Europa's history, radiolytically generated oxidized entities may have been subducted toward the ocean through occasional overturn of the ice shell, perhaps such that it produced an initially acidic ocean (Pappalardo et al., 1998; Bolton et al., 2002; Hand et al., 2006; Greenberg, 2010; Pasek and Greenberg, 2012; Kattenhorn and Prockter, 2014; Vance et al., 2016). It is under such conditions that proton and oxidation/reduction gradients imposed across precipitate mounds at submarine alkaline springs (electrons attracted outward, protons in toward the alkaline interior) could potentially have been harnessed through the emergence of metabolism and thereby life, much as thermal gradients can be harnessed to drive the onset of convection (Russell et al., 2003). As one example, given the potentially large flux of radiolytic sulfate, Zolotov and Shock (2003) calculated that sulfate is a strong enough oxidant to accept electrons from both hydrogen and methane, which could then drive the necessary redox gradient across hydrothermal systems at Europa's seafloor. Nitrate and/or nitrite are even more attractive electron acceptors, as they may be reduced to ammonium in such circumstances, which could be employed to augment the amination of the carboxylic acids (Raulin, 2005; Flores et al., 2016; Russell and Nitschke, 2017). Carbonate (or $\mathrm{CO}_{2}$ ) is a lower potential acceptor but has the advantage of also providing further carbon through a variant of the acetyl coenzyme-A pathway (Russell and Nitschke, 2017).

Fed by what may have been a plenitude of reductants (electron donors such as $\mathrm{H}_{2}, \mathrm{CH}_{4}$, and ferrous iron) from hydrothermal activity, and an ocean with dissolved oxidants providing a geochemical gradient, the first life-forms could potentially follow some of the same metabolic pathways 
known to be at, or near, the root of the earliest life on Earth, that is, acetogenesis and methanotrophy (Russell and Martin, 2004; Nitschke and Russell, 2013; Russell and Nitschke, 2017; cf. Mikucki et al., 2009; Waite et al., 2017). If, during periods of slowed or stalled ice-ocean exchange, $\mathrm{SO}_{4}{ }^{2-}$ and $\mathrm{CO}_{2}$ and other electron acceptors were to be rapidly drawn down by participants in the biofilm, the oxidant-limiting conditions would be created and an "oxidant crisis" ensue. Models for transport of material within Europa's ocean indicate that hydrothermal plumes could be well constrained within the ocean (primarily by the Coriolis force and thermal gradients), leading to effective delivery through the ocean to the ice-water interface (Goodman et al., 2004; Goodman and Lenferink, 2012; Travis et al., 2012; Goodman, 2016). Organisms fortuitously transported from hydrothermal systems to the ice-water interface along with unspent fuels could potentially access a larger abundance of oxidants directly from the ice (Fig. 1) (e.g., Raymond et al., 2008). Importantly, oxidants might only be available where the ice surface has been driven to the base of the ice shell (e.g., Showman and Han, 2005). These sites could be geographically separated from upwelling sites within the ice shell driven by heat from hydrothermalism. Opportunistic life-forms could rely on lateral transport (e.g., ocean currents) along the ice-water interface to reach sites of downwelling convection in the ice that might bring radiolytically produced oxidants to the ocean (Fig. 1).

In such chemostatic conditions, a coevolutionary mutualistic drive toward lowering the minimal requirement for electron acceptors while recycling electrons would be expected, homologous to dynamic growth in a Winogradsky column (e.g., Schlegel and Jannasch, 2006; Castelle et al., 2015; cf. Fernández et al., 1999; Rinke et al., 2013). This ocean-deep chemostat presents a rather strange and challenging situation in which the long-term supply of useful hot electrons on the one hand, and of oxidants on the other, would be dramatically separated spatially by the $\sim 100 \mathrm{~km}$ deep ocean desert. Yet carbon as abiotic $\mathrm{CH}_{4}$ and formate exhaled hydrothermally from the crust, as well as in the form of $\mathrm{CO}_{2}$ from melting of the ice shell, could be continually supplied to autotrophic metabolic life-forms. Heterotrophic activity could recycle much of the autotrophic waste and detritus and contribute to a thickening of the ice-bound biosphere, undiluted by sediment - a contrast to our own deep biosphere (Kepner et al.,1998; López-Bueno et al., 2009; Rinke et al., 2013). In these chemostatic conditions, populations could grow asymptotically to a stable, though dynamic, equilibrium (Fernández et al., 1999; De Roos, 2004; Nealson et al., 2005).

Such an evolutionary drive for speciation and potential diversity of metabolisms could create an efficient and durable ecosystem that would continue to draw down nutrients by maximizing the overall cellular electron-to-nutrient flux, thus simultaneously increasing a microbe's own waste, to be absorbed as nutrients by their adaptable and less discriminating heterotrophic neighbors ( $c f$. Braakman et al., 2017; and see Fernández et al., 1999; Rinke et al., 2013). Typical, rather insoluble, trace elements could also be recycled in organic chelates ( $c f$. Milner-White and Russell, 2008). Thus, a strong effect of electron uptake would be to minimize other waste products through recycling by emerging heterotrophic, fermenting, and symbiotic microbes, and nanobes (Uwins et al., 1998; Rinke et al., 2013; Kuhn et al., 2014; Luef et al., 2015; cf. Stolz, 2017).
The overall effect of this process would be to strongly concentrate any putative cells by many orders of magnitude at these sites. This could be a critical consideration for life detection and the finding of potential biosignatures within $\mathrm{Eu}-$ ropa's ice (Hand et al., 2017). An active ice-water interface could reach cell densities of $10^{5}$ to $10^{8}$ cells $\mathrm{mL}^{-1}$, comparable to microbial mats or other chemically rich interfaces on Earth (Nealson et al., 2005; Hand et al., 2009) (Fig. 2C). This is considerably higher than cell densities found in the accretion ice of subglacial Lake Vostok in Antarctica of $\sim 10^{2}$ cells $\mathrm{mL}^{-1}$, which is perhaps one of the most relevant environmental analogues for Europa that can be found on Earth (Christner et al., 2006). Whether or not cell densities at the ice-water interface are conserved and represented via transport to the surface depends on the variety of potential mechanisms that could deliver basal ice to the surface (see, e.g., Collins and Nimmo, 2009). Prospects for life detection on ice-covered ocean worlds could be significantly enhanced if the ice-water interface harbors enough redox chemistry to sustain sub-ice shell biofilms (McKay et al., 2008, 2014; Hand et al., 2009, 2017; Shock and Boyd, 2015; Lorenz, 2016; Nimmo and Pappalardo, 2016; Sparks et al., 2016). Detection techniques are itemized in Hand et al. (2017) where, for example, atomic force microscopy as well as deep-UV Raman spectroscopy are considered (Sivakumar et al., 2015; Abbey et al., 2017). It is notable that atomic force microscopes have already been flown on the Phoenix and Rosetta missions (Pike et al., 2011; Bentley et al., 2016).

\section{Discussion}

That we have not considered methanogenesis as a possible metabolism needs explanation. Of course, methanogens on Earth do need to expel excess electrons, but these are generally borne away physically as methane gas itself, although some do appear to reduce Fe(III) at the same time (Vargas et al., 1998). Be that as it may, it is doubtful if methanogens would have made up a significant portion of the microbial population on Europa or other icy moons given the high concentrations of abiotic methane likely emanating from the reduced mantles (Gaidos et al., 1999, 2009; McDermott et al., 2015; cf. Waite et al., 2017). And they were certainly unlikely to have emerged at an early stage in the emergence of life on such a moon, as conditions would have strongly favored methanotrophy instead, with sulfate, sulfur, and/or ferric iron as oxidants (Nitschke and Russell, 2013; McGlynn, 2017; Russell and Nitschke, 2017; cf. Milucka et al., 2012; Egger et al., 2017).

\section{Conclusions}

The dynamic communities comprising any sub-ice-shell biosphere could constitute a habitable zone, manifested as microbial mats concentrated around oxidant-rich ice-shell sites at the down-welling regions of thermally unstable regions at the ice-water interface (Goodman et al., 2004). An expectation of this physiochemically dynamic freeze-thaw scenario is that cells would be periodically trapped in the ice, and these communities brought to the surface in a cryogenic state along with their ambient environmental molecules (Showman and Han, 2005; Porco et al., 2006; Spencer et al., 2006; Waite et al., 2006, 2017; Spitale and Porco, 2007; McKay et al., 2008; Roth et al. 2014; Nadeau et al., 2016; Vance et al., 2016; Hand et al., 2017). Thus, along with the standard methods for flying through possible plumes, and deploying landers, future 
missions could eventually use robotic capabilities designed for exploring the ice-water interface (Berisford et al., 2012; Ananthaswamy, 2013).

Future missions to search for life on Europa (Hand et al., 2017), a young Enceladus (McKay et al., 2014; Ćuk et al., 2016), and other ocean words will be tasked with seeing if life emerged afresh elsewhere, independently from Earth where Snowball events were relatively short-lived (Harland, 1964; Kirschvink, 1992; Hoffman and Schrag, 2002; Parkinson et al., 2008; Blanc et al., 2016; Barge and White, 2017). A difference may be that the putative chemostatic biospheres on extraterrestrial, and even extrasolar, icy worlds may, for millions or billions of years, have been dynamically stable long after the emergence of life thereon, supported by serpentinizationlife's mother engine (Russell et al., 1989, 2010; Branscomb and Russell, 2013).

\section{Acknowledgments}

We thank Elbert Branscomb, Patrick Beckett, Laurie Barge, Grayson Chadwick, Usha Lingappa, Chris McKay, Bob Pappalardo, Norm Sleep, Christophe Sotin, and Steve Vance for help and discussions. M.J.R.'s research was supported by the National Aeronautics and Space Administration, through the NASA Astrobiology Institute under cooperative agreement issued through the Science Mission directorate; No. NNH13ZDA017C (Icy Worlds) at the Jet Propulsion Laboratory. A.E.M. was supported through NASA EPSCoR, cooperative agreement number NNX14AN24A.

\section{References}

Abbey, W.J., Bhartia, R., Beegle, L.W., DeFlores, L., Paez, V., Sijapati, K., Sijapati, S., Williford, K., Tuite, M., Hug, W., and Reid, R. (2017) Deep UV Raman spectroscopy for planetary exploration: the search for in situ organics. Icarus 290:201-214.

Ananthaswamy, A. (2013) Polar tech uncovers how frozen regions are changing. New Sci 217:16-17.

Anderson, J.D., Schubert, G., Jacobson, R.A., Lau, E.L., Moore, W.B., and Sjogren, W.L. (1998) Europa's differentiated internal structure: inferences from four Galileo encounters. Science 281:2019-2022.

Barge, L.M., and White, L.M. (2017) Experimentally testing hydrothermal vent origin of life on Enceladus and other icy/ocean worlds. Astrobiology 17:820-833.

Barge, L.M., Doloboff, I.J., Russell, M.J., VanderVelde, D., White, L.M., Stucky, G.D., Baum, M.M., Zeytounian, J., Kidd, R., and Kanik. I. (2014) Pyrophosphate synthesis in iron mineral films and membranes simulating prebiotic submarine hydrothermal precipitates. Geochim Cosmochim Acta 128:1-12.

Barge, L.M., Abedian, Y., Doloboff, I.J., Nuñez, J.E., Russell, M.J., Kidd, R.D., and Kanik, I. (2015a) Chemical gardens as flow-through reactors simulating natural hydrothermal systems. J Vis Exp doi:10.3791/53015.

Barge, L.M., Abedian, Y., Russell, M.J., Doloboff, I.J., Cartwright, J.H.E., Kidd, R.D., and Kanik, I. (2015b) From chemical gardens to fuel cells: generation of electrical potential and current across self-assembling iron mineral membranes. Angew Chem Int Ed 54:8184-8187.

Bentley, M.S., Schmied, R., Mannel, T., Torkar, K., Jeszenszky, H., Romstedt, J., Levasseur-Regourd, A.C., Weber, I., Jessberger, E.K., Ehrenfreund, P., and Koeberl, C. (2016) Ag- gregate dust particles at comet $67 \mathrm{P} /$ Churyumov-Gerasimenko. Nature 537:73-75.

Berisford, D.F., Leichty, J.M., Klesh, A.T., Matthews, J.B., and Hand, K.P. (2012) Buoyant rover for under-ice exploration [abstract \#C13E-0655]. In AGU 2012 Fall Meeting, American Geophysical Union, Washington, DC.

Bernal, J.D. (1960) The problem of stages in biopoesis. In Aspects of the Origin of Life, edited by M. Florkin, Pergamon Press, New York, pp 30-45.

Blanc, M., Jones, G., Prieto-Ballesteros, O., Mimoun, D., Masters, A., Kempf, S., Iess, L., Martins, Z., Lorenz, R., Lasue, J., Andre, N., Bills, B.G., Choblet, G., Collins, G., Cremonese, G., Garnier, P., Hand, K., Hartogh, P., Khurana, K.K., Stephan, K., Tosi, F., Vance, S.D., van Hoolst, T., Westall, F., Wolwerk, M., Cooper, J.F., Sittler, E.C., Brinckerhoff, W., Hurford, T., and the Europa Initiative. (2016) Europa habitability and extant life exploration with combined flyby-lander-orbiter mission [abstract 4026]. In $3^{\text {rd }}$ International Workshop on Instrumentation for Planetary Missions, Lunar and Planetary Institute, Houston.

Bolton, S.J., Janssen, M., Thorne, R., Levin, S., Klein, M., Gulkis, S., Bastian, T., Sault, R., Elachi, C., Hofstadter, M., and Bunker, A. (2002) Ultra-relativistic electrons in Jupiter's radiation belts. Nature 415:987-991.

Braakman, R., Follows, M.J., and Chisholm, S.W. (2017) Metabolic evolution and the self-organization of ecosystems. Proc Natl Acad Sci USA 114:E3091-E3100.

Branscomb, E. and Russell, M.J. (2013) Turnstiles and bifurcators: the disequilibrium converting engines that put metabolism on the road. Biochim Biophys Acta Bioenergetics 1827:62-78.

Branscomb, E., Biancalani, T., Goldenfeld, N., and Russell, M.J. (2017) Escapement mechanisms and the conversion of disequilibria: the engines of creation. Phys Rep 677:1-60.

Carlson, R.W., Anderson, M.S., Johnson, R.E., Schulman, M.B., and Yavrouian, A.H. (2002) Sulfuric acid production on Europa: the radiolysis of sulfur in water ice. Icarus 157:456-463.

Castelle, C.J., Wrighton, K.C., Thomas, B.C., Hug, L.A., Brown, C.T., Wilkins, M.J., Frischkorn, K.R., Tringe, S.G., Singh, A., Markillie, L.M., and Taylor, R.C. (2015) Genomic expansion of domain Archaea highlights roles for organisms from new phyla in anaerobic carbon cycling. Curr Biol 25:690-701.

Christner, B.C., Royston-Bishop, G., Foreman, C.M., Arnold, B.R., Tranter, M., Welch, K.A., Lyons, W.B., Tsapin, A.I., Studinger, M., and Priscu, J.C. (2006) Limnological conditions in subglacial Lake Vostok, Antarctica. Limnol Oceanogr 51: 2485-2501.

Chyba, C.F. and Hand, K.P. (2001) Life without photosynthesis. Science 292:2026-2027.

Collins, G. and Nimmo, F. (2009) Chaotic terrain on Europa. In Europa, The University of Arizona Space Science Series. University of Arizona Press, Tucson, pp 259-281.

Ćuk, M., Dones, L., and Nesvorný, D. (2016) Dynamical evidence for a late formation of Saturn's moons. Astrophys $J$ 820, doi:10.3847/0004-637X/820/2/97.

De Roos, A.M. (2004) Modeling Population Dynamics, Institute for Biodiversity and Ecosystem Dynamics, Population Biology Section, University of Amsterdam, Amsterdam, The Netherlands.

Egger, M., Hagens, M., Sapart, C.J., Dijkstra, N., van Helmond, N.A., Mogollón, J.M., Risgaard-Petersen, N., van der Veen, C., Kasten, S., Riedinger, N., and Böttcher, M.E. (2017) Iron oxide reduction in methane-rich deep Baltic Sea sediments. Geochim Cosmochim Acta 207:256-276.

Fernández, A., Huang, S., Seston, S., Xing, J., Hickey, R., Criddle, C., and Tiedje, J. (1999) How stable is stable? Function 
versus community composition. Appl Environ Microbiol 65: 3697-3704.

Flores, E., Barge, L., VanderVelde, D., Kallas, K., Baum, M.M., Russell, M.J., and Kanik, I. (2016) Amino acid synthesis in seafloor environments on icy worlds [id.323.02]. In American Astronomical Society, DPS meeting \#48, American Astronomical Society, Washington, DC.

Fuchs, G. (1989) Alternative pathways of autotrophic $\mathrm{CO}_{2}$ fixation. In Autotrophic Bacteria, edited by H.G. Schlegel and B. Bowen, Science Technology, Madison, WI, pp 365-382.

Fuchs, G. (2011) Alternative pathways of carbon dioxide fixation: insights into the early evolution of life. Annu Rev Microbiol 65:631-658.

Gaidos, E., Marteinsson, V., Thorsteinsson, T., Jóhannesson, T., Rúnarsson, Á.R., Stefánsson, A., Glazer, B., Lanoil, B. Skidmore, M., Han, S., and Miller, M. (2009) An oligarchic microbial assemblage in the anoxic bottom waters of a volcanic subglacial lake. ISME J 3:486-497.

Gaidos, E.J., Nealson, K.H., and Kirschvink, J.L. (1999) Life in ice-covered oceans. Science 284:1631-1633.

Gaillard, F., Scaillet, B., Pichavant, M., and Iacono-Marziano, G. (2015) The redox geodynamics linking basalts and their mantle sources through space and time. Chem Geol 418: 217-233.

Génin, J.-M.R., Aïssa, R., Géhin, A., Abdelmoula, M., Benali, O., Ernstsen, V., Ona-Nguema, G., Upadhyay, C., and Ruby, C. (2005) Fougerite and $\mathrm{Fe}^{\mathrm{II}-\mathrm{III}}$ hydroxycarbonate green rust; ordering, deprotonation and/or cation substitution; structure of hydrotalcite-like compounds and mythic ferrosic hydroxide $\mathrm{Fe}(\mathrm{OH})_{(2+\mathrm{x})}$. Solid State Sciences 7:545-572.

Génin, J.-M.R., Ruby, C., Géhin, A., and Refait, Ph. (2006) Synthesis of green rust by oxidation of $\mathrm{Fe}(\mathrm{OH})_{2}$, their products of oxidation and reduction of ferric oxyhydroxides; $\mathrm{E}_{\mathrm{h}}-\mathrm{pH}$ Pourbaix diagrams. Comptes Rendus Geosciences 338: 433-446.

Génin, J.-M.R., Renard, A., and Ruby, C. (2008) Fougérite Fe ${ }^{\mathrm{II}-\mathrm{III}}$ oxyhydroxycarbonate in environmental chemistry and nitrate reduction. Hyperfine Interactions 186:31-37.

Glein, C.R., Baross, J.A., and Waite, J.H. (2015) The pH of Enceladus' ocean. Geochim Cosmochim Acta 162:202-219.

Goodman, J. (2016) Snow, slush, or solid? Latent heat transfer through porous high-pressure ice layers in icy satellites and other water worlds [abstract 2836]. In $47^{\text {th }}$ Lunar and Planetary Science Conference, Lunar and Planetary Institute, Houston.

Goodman, J.C. and Lenferink, E. (2012) Numerical simulations of marine hydrothermal plumes for Europa and other icy worlds. Icarus 221:970-983.

Goodman, J.C., Collins, G.C., Marshall, J., and Pierrehumbert, R.T. (2004) Hydrothermal plume dynamics on Europa: implications for chaos formation. J Geophys Res: Planets 109, doi:10.1029/2003JE002073.

Greenberg, R. (2010) Transport rates of radiolytic substances into Europa's ocean: implications for the potential origin and maintenance of life. Astrobiology 10:275-283.

Halevy, I. and Bachan, A. (2017) The geologic history of seawater pH. Science 355:1069-1071.

Halevy, I., Alesker, M., Schuster, E.M., Popovitz-Biro, R., and Feldman, Y. (2017) A key role for green rust in the Precambrian oceans and the genesis of iron formations. Nat Geosci 10:135-139.

Hand, K.P. and Brown, M.E. (2013) Keck II observations of hemispherical differences in $\mathrm{H}_{2} \mathrm{O}_{2}$ on Europa. Astrophys J Lett 766:L21.
Hand, K.P., Chyba, C.F., Carlson, R.W., and Cooper, J.F. (2006) Clathrate hydrates of oxidants in the ice shell of Europa. Astrobiology 6:463-482.

Hand, K.P., Carlson, R.W., and Chyba, C.F. (2007) Energy, chemical disequilibrium, and geological constraints on Europa. Astrobiology 7:1006-1022.

Hand, K.P., Chyba, C.F., Priscu, J.C., Carlson, R.W., and Nealson, K.H. (2009) Astrobiology and the potential for life on Europa. In Europa, edited by R.T. Pappalardo, W.B. McKinnon, and K. Khurana, University of Arizona Press, Tucson, pp 589-629.

Hand, K.P., Murray, A.E., Garvin, J.B., Brinkerhoff, W.B., Edgett, K.S., Ehlmann, B.L., German, C.R., Hoehler, T.M., Horst, S.M., Lunine, J.I., Nealson, K.H., Paranicas, C., Schmidt, B.E., Smith, D.E., Rhoden, A.R., Russell, M.J., Templeton, A.S., Willis, P.A., Yingst, R.A., Phillips, C.B., Cable, M.L., Craft, K.L., Hofmann, A.E., Nordheim, T.A., Pappalardo, R.P., and the Project Engineering Team. (2017) Report of the Europa Lander Science Definition Team, JPL D-97667, NASA, Washington, DC. Available online at https://solarsystem.nasa.gov/docs/ Europa_Lander_SDT_Report_2016.pdf

Harland, W.B. (1964) Critical evidence for a great infraCambrian glaciation. Geolog Rundsch 54:45-61.

Herschy, B., Whicher, A., Camprubi, E., Watson, C., Dartnell, L., Ward, J., Evans, J.R.G., and Lane, N. (2014) An origin-oflife reactor to simulate alkaline hydrothermal vents. $J$ Mol Evol 79:213-227.

Hoffman, P.F. and Schrag, D.P. (2002) The snowball Earth hypothesis: testing the limits of global change. Terra Nova 14:129-155.

Kalousová, K., Souček, O., Tobie, G., Choblet, G., and Čadek, O. (2014) Ice melting and downward transport of meltwater by two-phase flow in Europa's ice shell. $J$ Geophys Res: Planets 119:532-549.

Kattenhorn, S.A. and Prockter, L.M. (2014) Evidence for subduction in the ice shell of Europa. Nat Geosci 7:762-767.

Kelley, D.S., Karson, J.A., Blackman, D.K., Früh-Green, G.L., Butterfield, D.A., Lilley, M.D., Olson, E.J., Schrenk, M.O., Roe, K.K., Lebon, G.T., Rivizzigno, P., and the AT3-60 Shipboard Party. (2001) An off-axis hydrothermal vent field near the Mid-Atlantic Ridge at $30^{\circ} \mathrm{N}$. Nature 412:145-149.

Kepner, R.L., Wharton, R.A., and Suttle, C.A. (1998) Viruses in Antarctic lakes. Limnol Oceanogr 43:1754-1761.

Kirschvink, J.L. (1992) Late Proterozoic low-latitude global glaciation: the Snowball Earth. In The Proterozoic Biosphere, edited by J.W. Schopf and C. Klein, Cambridge University Press, Cambridge, UK, pp 51-52.

Kuhn, E., Ichimura, A.S., Peng, V., Fritsen, C.H., Trubl, G., Doran, P.T., and Murray, A.E. (2014) Brine assemblages of ultrasmall microbial cells within the ice cover of Lake Vida, Antarctica. Appl Environ Microbiol 80:3687-3698.

Lassiter, R.R. (1986) A theoretical basis for modeling element cycling. In Mathematical Ecology: An Introduction, edited by T.G. Hallam and S.A. Levin, Springer, Berlin, pp 341-377.

Lin, L.-H., Wang, P.L., Rumble, D., Lippmann-Pipke, J., Boice, E., Pratt, L.M., Sherwood Lollar, B., Brodie, E.L., Hazen, T.C., Andersen, G.L., and DeSantis, T.Z. (2006) Long-term sustainability of a high-energy, low-diversity crustal biome. Science 314:479-482.

Loeffler, M.J. and Hudson, R.L. (2015) Descent without modification? The thermal chemistry of $\mathrm{H}_{2} \mathrm{O}_{2}$ on Europa and other icy worlds. Astrobiology 15:453-461. 
López-Bueno, A., Tamames, J., Velázquez, D., Moya, A., Quesada, A., and Alcamí, A. (2009) High diversity of the viral community from an Antarctic lake. Science 326:858-861.

Lorenz, R.D. (2016) Europa ocean sampling by plume flythrough: astrobiological expectations. Icarus 267:217-219.

Luef, B., Frischkorn, K.R., Wrighton, K.C., Holman, H.Y.N., Birarda, G., Thomas, B.C., Singh, A., Williams, K.H., Siegerist, C.E., Tringe, S.G., and Downing, K.H. (2015) Diverse uncultivated ultra-small bacterial cells in groundwater. Nat Commun 6, doi:10.1038/ncomms 7372 .

Martin, W. and Russell, M.J. (2007) On the origin of biochemistry at an alkaline hydrothermal vent. Philos Trans $R$ Soc Lond $B$ Biol Sci 362:1887-1925.

Martin, W., Baross, J., Kelley, D., and Russell, M.J. (2008) Hydrothermal vents and the origin of life. Nat Rev Microbiol 6:806-814.

McCollom, T.M. and Donaldson, C. (2016) Generation of hydrogen and methane during experimental low-temperature reaction of ultramafic rocks with water. Astrobiology 16: 389-406.

McCord, T.B., Orlando, T.M., Teeter, G., Hansen, G.B., Sieger, M.T., Petrik, N.G., and Van Keulen, L. (2001) Thermal and radiation stability of the hydrated salt minerals epsomite, mirabilite, and natron under Europa environmental conditions. J Geophys Res: Planets 106:3311-3319.

McDermott, J.M., Seewald, J.S., German, C.R., and Sylva, S.P. (2015) Pathways for abiotic organic synthesis at submarine hydrothermal fields. Proc Natl Acad Sci USA 112:7668-7672.

McGlynn, S.E. (2017) Energy metabolism during anaerobic methane oxidation in ANME archaea. Microbes Environ 32:5-13.

McKay, C.P., Porco, C.C., Altheide, T., Davis, W.L., and Kral, T.A. (2008) The possible origin and persistence of life on Enceladus and detection of biomarkers in the plume. Astrobiology 8:909-919.

McKay, C.P., Anbar, A.D., Porco, C., and Tsou, P. (2014) Follow the plume: the habitability of Enceladus. Astrobiology 14:352-355.

Mikucki, J.A., Pearson, A., Johnston, D.T., Turchyn, A.V., Farquhar, J., Schrag, D.P., Anbar, A.D., Priscu, J.C., and Lee, P.A. (2009) A contemporary microbially maintained subglacial ferrous “ocean." Science 324:397-400.

Milner-White, E.J. and Russell, M.J. (2008) Predicting the conformations of peptides and proteins in early evolution. Biol Direct 3, doi:10.1186/1745-6150-3-3.

Milucka, J., Ferdelman, T.G., Polerecky, L., Franzke, D., Wegener, G., Schmid, M., Lieberwirth, I., Wagner, M., Widdel, F., and Kuypers, M.M.M. (2012) Zero-valent sulphur is a key intermediate in marine methane oxidation. Nature 491:541-546.

Mitchell, P. (1961) Coupling of phosphorylation to electron and hydrogen transfer by a chemiosmotic type of mechanism. Nature 191:144-148.

Mitchell, P. (1967) Proton-translocation phosphorylation in mitochondria, chloroplasts and bacteria: natural fuel cells and solar cells. Fed Proc 26:1370-1379.

Mloszewska, A.M., Pecoits, E., Cates, N.L., Mojzsis, S.J., O'Neil, J., Robbins, L.J., and Konhauser, K.O. (2012) The composition of Earth's oldest iron formations: the Nuvvuagittuq Supracrustal Belt (Québec, Canada). Earth Planet Sci Lett 317:331-342.

Murray, A.E., Rack, F.R., Zook, R., Williams, M.J., Higham, M.L., Broe, M., Kaufmann, R.S., and Daly, M. (2016) Microbiome composition and diversity of the ice-dwelling sea anemone, Edwardsiella andrillae. Integr Comp Biol 56:542-555.
Nadeau, J., Lindensmith, C., Deming, J.W., Fernandez, V.I., and Stocker, R. (2016) Microbial morphology and motility as biosignatures for outer planet missions. Astrobiology 16:755-774.

Nealson, K.H., Belz, A., and McKee, B. (2002) Breathing metals as a way of life: geobiology in action. Antonie Van Leeuwenhoek 81:215-222.

Nealson, K.H., Inagaki, F., and Takai, K. (2005) Hydrogendriven subsurface lithoautotrophic microbial ecosystems (SLiMEs): Do they exist and why should we care? Trends Microbiol 13:405-410.

Niederberger, T.D., Perreault, N.N., Lawrence, J.R., Nadeau, J.L., Mielke, R.E., Greer, C.W., Andersen, D.T., and Whyte, L.G. (2009) Novel sulfur-oxidizing streamers thriving in perennial cold saline springs of the Canadian high Arctic. Environ Microbiol 11:616-629.

Nimmo, F. and Pappalardo, R.T. (2016) Ocean worlds in the outer Solar System. J Geophys Res: Planets 121:1378-1399.

Nimmo, F., Pappalardo, R., and Cuzzi, J. (2007) Observational and theoretical constraints on plume activity at Europa [abstract \#P51E-05]. In AGU 2007 Fall Meeting, American Geophysical Union, Washington, DC.

Nitschke, W. and Russell, M.J. (2011) Redox bifurcations; how they work and what they mean to extant life and (potentially) to its inorganic roots. BioEssays 34:106-109.

Nitschke, W. and Russell, M.J. (2013) Beating the acetyl coenzyme-A pathway to the origin of life. Philos Trans $R$ Soc Lond B Biol Sci 368, doi:10.1098/rstb.2012.0258.

Nitschke, W., McGlynn, S.E., Milner-White, J.E., and Russell, M.J. (2013) On the antiquity of metalloenzymes and their substrates in bioenergetics. Biochim Biophys Acta Bioenergetics 1827:871-881.

Pappalardo, R.T., Head, J.W., Greeley, R., Sullivan, R.J., Pilcher, C., Schubert, G., Moore, W.B., Carr, M.H., Moore, J.M., Belton, M.J.S., and Goldsby, D.L. (1998) Geological evidence for solid-state convection in Europa's ice shell. Nature 391:365-368.

Parkinson, C.D., Liang, M.C., Yung, Y.L., and Kirschivnk, J.L. (2008) Habitability of Enceladus: planetary conditions for life. Orig Life Evol Biosph 38:355-369.

Pasek, M.A. (2016) Schreibersite on the early Earth: scenarios for prebiotic phosphorylation. Geoscience Frontiers 8:329-335.

Pasek, M.A. and Greenberg, R. (2012) Acidification of Europa's subsurface ocean as a consequence of oxidant delivery. Astrobiology 12:151-159.

Pasek, M.A., Mousis, O., and Lunine, J.I. (2011) Phosphorus chemistry on Titan. Icarus 212:751-761.

Peacock, C.L., Lalonde, S.V., and Konhauser, K.O. (2016) Iron minerals as archives of Earth's redox and biogeochemical evolution. EMU Notes in Mineralogy 17:113-164.

Pike, W.T., Staufer, U., Hecht, M.H., Goetz, W., Parrat, D., Sykulska-Lawrence, H., Vijendran, S., and Madsen, M.B. (2011) Quantification of the dry history of the martian soil inferred from in situ microscopy. Geophys Res Lett 38, doi:10.1029/2011gl49896.

Porco, C.C., Helfenstein, P., Thomas, P.C., Ingersoll, A.P., Wisdom, J., West, R., Neukum, G., Denk, T., Wagner, R., Roatsch, T., Kieffer, S., Turtle, E., McEwen, A., Johnson, T.V., Rathbun, J., Veverka, J., Wilson, D., Perry, J., Spitale, J., Brahic, A., Burns, J.A., DelGenio, A.D., Dones, L., Murray, C.D., and Squyres, S. (2006) Cassini observes the active south pole of Enceladus. Science 311:1393-1401.

Raulin, F. (2005) Exo-astrobiological aspects of Europa and Titan: from observations to speculations. In The Outer Planets and Their Moons: Comparative Studies of the Outer Planets prior 
to the Exploration of the Saturn System by Cassini-Huygens, edited by T. Encrenaz, R. Kallenbach, T.C. Owen, and C. Sotin, Springer, Dordrecht, The Netherlands, pp 471-487.

Raymond, J.A., Christner, B.C., and Schuster, S.C. (2008) A bacterial ice-binding protein from the Vostok ice core. Extremophiles 12:713-717.

Rinke, C., Schwientek, P., Sczyrba, A., Ivanova, N.N., Anderson, I.J., Cheng, J.F., Darling, A., Malfatti, S., Swan, B.K., Gies, E.A., and Dodsworth, J.A. (2013) Insights into the phylogeny and coding potential of microbial dark matter. Nature 499: 431-437.

Roth, L., Saur, J., Retherford, K.D., Strobel, D.F., Feldman, P.D., McGrath, M.A., and Nimmo, F. (2014) Transient water vapor at Europa's south pole. Science 343:171-174.

Russell, M.J. (2007) The alkaline solution to the emergence of life: energy, entropy and early evolution. Acta Biotheor 55: 133-179.

Russell, M.J. and Hall, A.J. (1997) The emergence of life from iron monosulphide bubbles at a submarine hydrothermal redox and pH front. J Geol Soc Lond 154:377-402.

Russell, M.J. and Martin, W. (2004) The rocky roots of the acetyl-CoA pathway. Trends Biochem Sci 29:358-363.

Russell, M.J. and Nitschke, W. (2017) Methane: fuel or exhaust at the emergence of life? Astrobiology 17, doi:10.1089/ast .2016.1599.

Russell, M.J., Hall, A.J., and Turner, D. (1989) In vitro growth of iron sulphide chimneys: possible culture chambers for origin-of-life experiments. Terra Nova 1:238-241.

Russell, M.J., Daniel, R.M., Hall, A.J., and Sherringham, J. (1994) A hydrothermally precipitated catalytic iron sulphide membrane as a first step toward life. J Mol Evol 39:231-243.

Russell, M.J., Hall, A.J., and Mellersh, A.R. (2003) On the dissipation of thermal and chemical energies on the early Earth: the onsets of hydrothermal convection, chemiosmosis, genetically regulated metabolism and oxygenic photosynthesis. In Natural and Laboratory-Simulated Thermal Geochemical Processes, edited by R. Ikan, Kluwer Academic Publishers, Dordrecht, The Netherlands, pp 325-388.

Russell, M.J., Hall, A.J., and Martin, W. (2010) Serpentinization as a source of energy at the origin of life. Geobiology 8:355-371.

Russell, M.J., Barge, L.M., Bhartia, R., Bocanegra, D., Bracher, P.J., Branscomb, E., Kidd, R., McGlynn, S., Meier, D.H., Nitschke, W., Shibuya, T., Vance, S., White L., and Kanik, I. (2014) The drive to life on wet and icy worlds. Astrobiology 14:308-343.

Schlegel, H.G. and Jannasch, H.W. (2006) Prokaryotes and their habitats. In The Prokaryotes, Vol. 1, edited by $\mathrm{M}$. Dworkin, S. Falkow, E. Rosenberg, K.-H. Schleifer, and E. Stackebrandt, Springer, New York, pp 137-184.

Schmidt, B.E., Blankenship, D.D., Patterson, G.W., and Schenk, P.M. (2011) Active formation of 'chaos terrain' over shallow subsurface water on Europa. Nature 479:502-505.

Schoepp-Cothenet, B., van Lis, R., Philippot, P., Magalon, A., Russell, M.J., and Nitschke, W. (2012) The ineluctable requirement for the trans-iron elements molybdenum and/or tungsten in the origin of life. Sci Rep 2, doi:10.1038/srep00263.

Sherwood Lollar, B., Voglesonger, K., Lin, L.H., LacrampeCouloume, G., Telling, J., Abrajano, T.A., Onstott, T.C., and Pratt, L.M. (2007) Hydrogeologic controls on episodic $\mathrm{H}_{2}$ release from Precambrian fractured rocks-energy for deep subsurface life on Earth and Mars. Astrobiology 7:971-986.

Shock, E.L. and Boyd, E.S. (2015) Principles of geobiochemistry. Elements 11:395-401.
Showman, A.P. and Han, L. (2005) Effects of plasticity on convection in an ice shell: implications for Europa. Icarus 177:425-437.

Sivakumar, P., Fernández-Bravo, A., Taleh, L., Biddle, J.F., and Melikechi, N. (2015) Detection and classification of live and dead Escherichia coli by laser-induced breakdown spectroscopy. Astrobiology 15:144-153.

Sohl, F., Spohn, T., Breuer, D., and Nagel, K. (2002) Implications from Galileo observations on the interior structure and chemistry of the Galilean satellites. Icarus 157:104-119.

Sotin, C., Head, J.W., and Tobie, G. (2002) Europa: tidal heating of upwelling thermal plumes and the origin of lenticulae and chaos melting. Geophys Res Lett 29, doi:10.1029/ 2001 GL013844.

Sparks, W.B., Hand, K.P., McGrath, M.A., Bergeron, E., Cracraft, M., and Deustua, S.E. (2016) Probing for evidence of plumes on Europa with HST/STIS. Astrophys J 829, doi:10.3847/0004637X/829/2/121.

Spencer, J.R., Pearl, J.C., Segura, M., Flasar, F.M., Mamoutkine, A., Romani, P., Buratti, B.J., Hendrix, A.R., Spilker, L.J., and Lopes, R.M.C. (2006) Cassini encounters Enceladus: background and the discovery of a south polar hot spot. Science 311:1401-1405.

Spitale, J. and Porco, C. (2007) Association of the jets of Enceladus with the warmest regions on its south polar fractures. Nature 449:695-697.

Squyres, S.W. and Croft, S.K. (1986) The tectonics of icy satellites. In Satellites, edited by J.A. Burns and M.S. Matthews, University of Arizona Press, Tucson, pp 293-341.

Steele, R.H. (2003) Electromagnetic field generation by ATPinduced reverse electron transfer. Arch Biochem Biophys 411: $1-18$.

Stolz, J.F. (2017) Gaia and her microbiome. FEMS Microbiol Ecol 93, doi:10.1093/femsec/fiw247.

Szent-Györgyi, A. (1968) Bioelectronics. Science 161:988-990.

Tosca, N.J., Guggenheim, S., and Pufahl, P.K. (2016) An authigenic origin for Precambrian greenalite: implications for iron formation and the chemistry of ancient seawater. Geol Soc Am Bull 128:511-530.

Travis, B.J., Palguta, J., and Schubert, G. (2012) A whole-moon thermal history model of Europa: impact of hydrothermal circulation and salt transport. Icarus 218:1006-1019.

Uwins, P.J.R., Webb, R.I., and Taylor, A.P. (1998) Novel nanoorganisms from Australian sandstones. Am Mineral 83:15411550

Vance, S. and Goodman, J. (2009) Oceanography of an icecovered moon. In Europa, edited by R.T. Pappalardo, W.B. McKinnon, and K. Khurana, University of Arizona Press, Tucson, pp 459-484.

Vance, S., Harnmeijer, J., Kimura, J., Hussmann, H., DeMartin, B., and Brown, J.M. (2007) Hydrothermal systems in small ocean planets. Astrobiology 7:987-1005.

Vance, S., Bouffard, M., Choukroun, M., and Sotin, C. (2014) Ganymede's internal structure including thermodynamics of magnesium sulfate oceans in contact with ice. Planet Space Sci 96:62-70.

Vance, S.D., Hand, K.P., and Pappalardo, R.T. (2016) Geophysical controls of chemical disequilibria in Europa. Geophys Res Lett 43, doi:10.1002/2016GL068547.

Vargas, M., Kashefi, K., Blunt-Harris, E.L., and Lovley, D.R. (1998) Microbiological evidence for Fe(III) reduction on early Earth. Nature 395:65-67.

Vick-Majors, T.J., Mitchell, A.C., Achberger, A.M., Christner, B.C., Dore, J.E., Michaud, A.B., Mikucki, J.A., Purcell, 
A.M., Skidmore, M.L., Priscu, J.C., and the WISSARD Science Team. (2016) Physiological ecology of microorganisms in subglacial Lake Whillans. Front Microbiol 7, doi:10.3389/ fmicb.2016.01705.

Waite, J.H., Combi, M.R., Ip, W.-H., Cravens, T.E., McNutt, R.L., Jr., Kasprzak, W., Yelle, R., Luhmann, J., Niemann, H., Gell, D., Magee, B., Fletcher, G., Lunine, J., and Tseng, W.-L. (2006) Cassini Ion and Neutral Mass Spectrometer: Enceladus plume composition and structure. Science 311: 1419-1422.

Waite, J.H., Glein, C.R., Perryman, R.S., Teolis, B.D., Magee, B.A., Miller, G., Grimes, J., Perry, M.E., Miller, K.E., Bouquet, A., Lunine, J.I., Brockwell, T., and Bolton, S.J. (2017) Cassini finds molecular hydrogen in the Enceladus plume: evidence for hydrothermal processes. Science 356:155-159.

Watanabe, S., Mishima, K., and Matsuo, S. (1983) Isotopic ratios of carbonaceous materials incorporated in olivine crystals from the Hualalai Volcano, Hawaii. An approach to mantle carbon. Geochem J 17:95-104.

White, L.M., Bhartia, R., Stucky, G.D., Kanik, I., and Russell, M.J. (2015) Mackinawite and greigite in ancient alkaline hydrothermal chimneys: identifying potential key catalysts for emergent life. Earth Planet Sci Lett 430:105-114.

Windman, T., Zolotova, N., Schwandner, F., and Shock, E.L. (2007) Formate as an energy source for microbial metabolism in chemosynthetic zones of hydrothermal ecosystems. Astrobiology 7:873-890.
Wong, M.L., Charnay, B.D., Gao, P., Yung, Y.L., and Russell, M.J. (2017) Nitrogen oxides in early Earth's atmosphere as electron acceptors for life's emergence. Astrobiology 17, doi:10.1089/ast.2016.1473.

Wood, B.J., Walter, M.J., and Wade, J. (2006) Accretion of the Earth and segregation of its core. Nature 441:825-833.

Zolotov, M.Y. and Shock, E.L. (2003) Energy for biologic sulfate reduction in a hydrothermally formed ocean on Europa. J Geophys Res: Planets 108, doi:10.1029/2002JE001966.

Zolotov, M.Y. and Shock, E.L. (2004) A model for lowtemperature biogeochemistry of sulfur, carbon, and iron on Europa. J Geophys Res: Planets 109, doi:10.1029/2003JE002194.

Address correspondence to:

Michael J. Russell Planetary Chemistry and Astrobiology Group Section 3225 MS:183-301

Jet Propulsion Laboratory California Institute of Technology 4800 Oak Grove Drive Pasadena, CA 91109-8099

E-mail: mrussell@jpl.nasa.gov

Submitted 30 September 2016 Accepted 28 April 2017 